\title{
Oral Language Abuse In Teaching-Learning Activity At Kabupaten Sumba Tengah Elementary School
}

\section{Jefrey Oxianus Sabarua ${ }^{* 1}$, Alice Yeni Verawati Wote ${ }^{2}$}

1,2 Program Studi PGSD FKIP Universitas Halmahera

\section{ARTICLEIN \\ $\mathrm{FO}$ \\ Article history: \\ Received 12 August 2018 \\ Received in revised form \\ 19 September 2018 Accepted 17 October Available online 29 November 2018}

Keywords:

Oral languge abuse, verbal violence, teaching-learning interaction, primary school

\begin{abstract}
A B S T R A C T
This research bacground based on student's field experience of unsecure, oppressed, and fearful feelings caused by teacher's utterances in class teaching learning activities. The objectives of this researh are: to identify the lingual form of lingulistic units inside teacher's verbal violence/oral language abuse, to find teacher's verbal violence/oral abuse expressions, and to identify factors causing verbal violence or verbal harassment or oral language abuse done by teachers in Kabupaten Sumba Tengah. The method used is descriptive qualitative method. The data gathering method/data gathering technique uses "Simak and Cakap Method" (Observing and Conversing Methods) and analyzed using "Agih and Padan Method". The result of this study showed that verbal violence/verbal abuse are manifested in the lingual forms of linguistic units as words, phrases and sentences. The form of linguistic language tends to appear as exclamation sentences. Forms of verbal violences expressed by snaping, ignoring, uderestimating, humiliating in front of public/others, and doing accusations. Expressions tends to be manifested in the forms of accusations and humiliations toward children in front of others/public. The factors causing verbal abuse are education culture herritage of the past, teacher's lack of knowledge on verbal abuse, teacher's lack of vocubularies, their administrative tasks demands, discipling efforts, and local culture.
\end{abstract}

Copyright $(\complement$ Universitas Pendidikan Ganesha. All rights reserved.

\footnotetext{
* Corresponding author.

E-mail addresses: jefrysabarua@uniera.ac.id (Jefrey Oxianus Sabarua)
} 


\section{Introduction}

Utterance is a media by which somene legitimates himself through speaking in conveying particular meaning and intention (Wendra, 2006). The implementation example of Wendra's concept in learning process is often found learning process which is not nice, which caused students feel oppressed, fearful, and dibbled, and it is proved that there are teachers that use their authority to oppress, terror, and threaten their students, so that in-class-learning is shaped by teacher's will and not based on student's learning needs. Teaching learning strategy which is implemented tends to create one direction communication, and limited student's creativity in doing the learning, even found that there are forcement and violence toward students to meet teacher's demand and expectation. This kind of condition is kind of verbal abuse/ verbal violence, in which creates a situation where someone feels uncomfortable toward utterance (Brennan, 2006).

Violent actions done through utterance (verbal violence/ verbal abuse) done straightforward or not manifested in impolite and humiliating words toward students. Words, phrases and sentences uttered are meant to debase student's ability, giving negative labeling on children, and giving assumption that children are not capable, will give negative effects towards children's self image. Therefore, verbal violence/ verbal abuse is related to words, phrases and sentences to convey information, idea, desire, feeling, or messsage toward speaking partner (Bourdieu, 1997: 19).

Found in the research sample, there are some invention, there some indications show that verbal violence manifested in forms of oral/verbal satire which offend students also snap at them when the class is too noisy, students have not done their assignments, disgrace students when not doing exercises on blackboard and to punish students who creates disturbance in class when teaching learning takes place.

Oral/verbal violence done through those expressions, are meant to control bahavior to create expected situation and condition. During teaching learning process in elementary school, teacher rebukes students for not doing tasks.

(1) Teacher : "Which one have you written? Show me which part you have written." (with fierce eye look approaching the student).

Student $\quad:$ (His head bowed, scratching his head)

(2) Teacher : The others are bussy doing their tasks and both two of you are disturbing here. What such a great students you are!

Student $\quad$ : (head bowed down, silenced).

Teacher's utterance (1) expression shows his feeling when there is a students joking when the others are doing assignments. Then teacher's utterance (2), the teacher again gets angry seeing two students are not doing given task. Using oral/verbal abuse in the forms of snaping utterance and accusation threat just like shown in the above utterance is a strategy used by the teacher to control the class so that the teaching learning process will take place just like the teacher's expectation.

Teaching learning process involving oral abuse can give negative impact to students language acquisition. Unintentionally that oral abuse can give negative impact toward the children's language ability development. Under pressure, students will not be brave enough to give feed backs or arguments, this thing can influence children ability to speak or develop language. Beside that, when a child is not given freedom in opportunity to express him/herself since early stage, will lead to children lack of vocubularies which is caused by the limited given chance to think logically, draw conclusions, and analyze simple sentences (Subyantoro, 2012: 59)..

\section{Research Method}

This research/study is done to identify the lingual form of lingualistic units inside teacher's verbal violence/abuse, to find teacher's verbal violence expressions, and to identify factors causing verbal violence or verbal harassment or oral language abuse done by teachers in Kabupaten Sumba Tengah. So that readers can understand verbal violence happens in school environments. The method used in this study/research is descriptive qualitative method, using psycholinguistic approach. This approach is used to understand meaning of sound (comprehension) which relates to needed responding action after the comprehension/understanding achieved (Dardjowidjodjo, 2014: 59).

Data gathered in this study are words, phrases, and sentences derived from teacher's utterances containing oral abuse. Data gathering method used in this research is "Metode Simak"/Observing Method (Sudaryanto, 1993:136) with sap tapped technique to record teaching learning interaction in progress, then taking notes several things which were not recorded by camera, and also using "Metode Cakap"/ Conversing Method to support research data to be more complete. Data analysis uses "Agih dan Padan" /Agih and Padan Method (Sudaryanto, 1993: 139). Agih Method used to divide the lingual form of 
lingulistic units in teacher's utterances containing oral language abuse like words, phrases and sentences using "Metode Bagi Unsur Langsung" (BUL)/ Divide Straight Element Method, then when there are utterances using local language, or terms which familiar only in local society, the researcher used "Metode Ganti"/"Exchanging Method". In Padan Method, the researcher used "Pilah Unsur Penentu" (PUP) technique/"Sorting Determinant Element Technique" and also using further techniques such as "Hubung Banding Menyamakan" (HBS)/"Connect Compare Equate Technique", "Tekhnik Hubung Banding Memperbedakan" (HBS)/ "Connect Compare Distinguish Technique", and "Tekhnik Hubung Banding Menyamakan Hal Pokok" (HBSP)/ "Connect Compare Equate Dominant Element Technique" to analyze units of linguistic forms of teacher's utterances from oral language abuse expressions and factors causing verbal violence or verbal harassment or oral language abuse done by teachers in Kabupaten Sumba Tengah.

\section{Results and Discussion}

The Lingual Forms of Lingulistic Units Inside Teacher's Verbal Violence/Oral Language Abuse in Kabupaten Sumba Tengah Elementary School Teaching Learning Interactions.

Oral language abuse can be manifested in forms of linguistic units such words, phrases, sentences and discourses. According to result of this research, the researcher found that the forms of linguistic units containing oral language abuse including: words, phrases, and sentences. Here are the analysis on the forms of linguistic forms:

Words

Words containing oral/verbal languange abuse, can be identified in the sentence below:

"Mana yang kau tulis disitu Elon? Bagian mana yang kau tulis disitu? Mana...... Mana.....!"

(Mendekati, sambil melototi Elon).

"Which one you write there Elon? Which part you write there? Which one....! Which one...!" (approaching and glaring toward Elon)

The word "mana" (which one) in the above utterance, said by a teacher when seeing a student pretending to do assignment, so that the teacher approached him and asking about the result of his work. The word "mana" (means "which one") was expressed with angry intonation. Beside that, the teacher glared at him, intended to make him afraid, with purpose to force Elon doing his assignment more seriously. This kind of treatment will result in students having incooperative or antipathy toward teachers who often do oral language abuse which is accompanied with cruel acts (Sharpe. 2011:117).

\section{Phrases}

Phrases containing verbal/oral language abuse, can be identified in the sentences below:

(1) “Ada ko pu teman-teman yang bagus dong pu tulisan, baru engko, kau main gila di situ."

(2) "Kau tidak dengar guru. Kau pasang belakang guru di depan, kau punya masa depan nanti akan suram. Kau liat saja nanti. Catat sekarang......! Tidak tau malu......! Tidak ada juga yang onar, dan tidak ada juga yang komando kita belajar."

(1). There your friends' handwritings are good, but you, you just behaving like crazy there!" ("main gila" = "behaving like crazy" semantically means "doing stupid")

(2). You don't listen to the teacher. You faced backward while your teacher standing in front, you're future will be gloomy. You will proof it in the future. Take note now....! So shame...! No one becoming trouble maker and no one giving comand while we are learning."

(The phrase "Tidak tau malu" literally means "Doesn't know shame" but it will be more suitable translated according to it's semantic meaning "So shame...!")

Oral/verbal language contained in in Phrases number (1) and (2) in the above teacher's utterances, expressed through snaping, threat, and intimidation straightforwardly to the students in the classroom. It turned the atmosphere in tense, scarry and uncomfortable. Those utterances gave negative impacts toward students in the class. Using pressure and intimidation in coping with problems, basically not effective, since that is just one-way style of communication, taht only the teacher dominates the communication. In accordance with Surya (2014:337) who stated that in facing classroom problems, teachers ought to build two-ways communication, thus gives chance for students to convey their ideas.

\section{SENTENCES}

Based on the research data, oral/verbal language abuses were found in the form of sentences, among them are declarative sentences, imperative sentences, interogative sentences, and exclamative sentences. These are the teacher's utterances: 
(1). "Kalau duduk itu jangan kau kasi panjang itu pantat, nanti kau cepat tua." ("Don't seed reluctantly like a lazy, you can get older soon")

(2). "Ini kita sudah kelas empat 'ole', jangan macam orang yang tidak sekolah atau kelas satu sama sekali" ("We are in grade four 'yawl', don't behave like unschooled at all or like grade one children.")

(3). "Jemi dia tidak cakar, tapi dia hanya omong saja. Dua belas kau dapat dari mana lagi?" (Jemi doesn't write anything, he just talks too much. Where do you get this number 12 from?")

(4). "Aprilia dia menghayal saja di situ" ("Aprilia... just keep on daydreaming there.") The declarative sentences above contain verbal/oral language abuse in their semantic meanings which expressed by the teacher through straight quiping toward particular pertained student. This will cause the student feel ashamed, loosing confidence, feeling inferior, and difficult to determine his or her attitude.

(5). "Biarkan saja dia hitung sendiri! Kan dari tadi dia sudah ikut saya terangkan. Kalau kasi tau-kasi tau dia, nanti dia tidak bisa."

(Let him counts by himself! He has been paying attention to my explanation, hasn't he? If we keep on telling him the answer, he cannot do by himself.")

(6). "Ko baca baik-baik bahwa ini dia Tanya detik."

("Read carefully....and know that the demanded answer is in seconds.")

(7). "Jangan kau ba liat saya pu muka....hitung di situ."

("Don't stare at my face....just count!").

Oral/verbal language abuse can be identified in the forms of ignoring (5), quiping (6) and snaping/scolding (7). Leaving students in his or her ignorance or state of failing to undertand can make the student confused whether their work is true or not so that he or she looses motivation doing the task. Just like ignoring, quiping and scolding can also bring negative impacts toward children.

(8). "Dua belas kau dapat dari mana lagi?"

("Where can you get the number of twelve from?)

This form of interrogative sentence is expressed in blaming the chidren, to show that the result of his counting is wrong. Semantically, represent the act of underestimating and act of harassment of children ability, because that sentence is spoken in sinical tone or disrespect. That kind of thing is a kind of verbal/oral violence done by teacher on students, since inderectly the sentences spoken by teacher have got negative connotation to hummiliate students.

(9). "Jangan kau ukir mati punya itu angka-angka itu Elon. Hmmm itu sebentar yang kau tidak ada kerja sudah. Tidak kerja apa-apa sudah kau sebentar."

(You don't need to make a carving of those numbers Elon. Hmmm... it seems that you will not do anything. We'll see you end up doing nothing.")

(10). "Engko ini, sengaja betul kau. Bukan kau tulis dari nomor satu, kau pigi tulis di nomor empat."

("I think you do this intentionally. You do not do the assignment started from number one..You started from number four instead.)

(11). "Ini baru tidak sampe satu menit, mungkin dua detik saja dia ini. Begitu ibu tulis disana, mungkin dia sudah habis" ("This is less than one minute, maybe she is just two seconds. Soon after teacher write there, maybe she has ended.")

(12). "Kau perhatikan baik-baik. Bagaimana kita ajar seperti apa lagi sama kau."

(Pay attention. With what kind of other way should I teach you?)

(13). "Buat apa sudah ibu tulis ini kalau tidak ada guna buat engko?"

("Do you think I write this with no purpose for you?")

(14). "Kau jangan angnga-angnga saja kau tulis."

("Don't just staring at that...write down.")

(15). "Ini riski ini dia, begitu juga dia ini. Dia harap nyontek-nyontek, baru dapat seratus sudah dia ini."

(Riski, he always be like this. He relies on cheating, we'll se him gets one hundreed.")

(16)."Saya ulang-ulang supaya engko kuasai sedikit, tidak bisa juga."

("I have been repeating this in order that at least you catch a little bit but still you cannot.")

(17). "Ulang aling saja sudah tir tau."

("This has been repeated again and again but still you don't know")

(18). "Biar kau tidak cari, kau bunyi saja terus."

("Continue what you have been doing, you don't count, you keep on talking.")

(19). "Tadi waktu pembagian, tidak buat memang pembagian. Sekarang sudah kali, dia bagi."

(Previously in dividing task, you did not divide. Now in multiplication task, this time you do the dividing.") 
The above teacher's exclamation senttences or interjection sentences which shows disspointment or dissatisfaction. Sentences $(9,10,11,14,18$ and 19) are teacher's expression after seeing the students do not work the assignment seriously; sentences (12 and 13) are teachers expressions which uttered with a purpose in order to command students paying attention to teacher's explanations more seriously; sentence (15) is teacher's expression due to a student's bad habit cheating on exam; sentences (16 and 17) are teacher's dissatisfaction expression on children failure to understand explanation.

(20). "Ngomong empat puluh dua saja, macam ada yang mau makan sama engko."

("Your fear to say fourty two is as if like someone is going to swallow you up.")

(21). "Catat di kau punya hati di situ. Kau tidak dengar guru, kau punya masa depan nanti akan mati. Liat saja nanti. Catat sekarang! Tulis tanggal. Catat di kau punya hati di situ!"

("Take into your heart. You don't listen to the teacher, you future will be finished. You will see it. Now take notes! Write down this date. Write note in your very heart!"

(22). "Kau tidak dengar guru, Kau pasang belakang guru di depan, kau punya masa depan nanti akan suram"

("You don't listen to the teacher. You faced backward while your teacher standing in front, you're future will be gloomy.")

The above utterances data are exclamative or interjection sentences of anger. Sentence (20) expresses teacher's anger toward a student who are not confident enough to answer, resulting in uttering voice which is unclear in teacher's ears; sentences (21) and (22) are expessions of teacher's anger seeing a noisy class due to teacher's absence.

(23) "Tuhan ampun e ambu... engko hanya sakit dua hari, tujuh dikurangi empat sa, su tidak tau."

("Oh my God.... you're only sick for two days, now you don't know what equals seven minus four.")

This is the data of teacher's utterance which can be said as interjection sentence of surprise. Sentence (23) is teacher's expression toward a student who are not able to answer a given question.

According to the stated above utterances data, can be concluded that oral/verbal language abuse in interjections/exclamative sentences are expressed in blaming students (19), underestimate student's ability (16), insulting students (10 and 23), humiliating students in front of others (11, 12, 13 and 14), accusing students (15), quiping students (18), scolding (20), and threating (21 and 22).

Fitriana and Sutanto (2015:82) stated that oral/verbal language abuse can be manifested in intimidation, underestimating and puting someone to shame, insulting, calling a student by his or her parent's name, ignoring or rejecting and giving extreme punishment. According to Tower (2002:32) states that forms of verbal abuse/violence can be expressed by scolding, judging, swearing, snaping and cursing, clarificating, ignoring, puting aside, underestimating, belittling, lowering, and humiliting.

Teacher's Verbal Violence/Oral Abuse Expressions in Elementary Schools Teaching Learning Interactions in Kabupaten Sumba Tengah.

According to research finding in the field, violence happens in teaching learning interactions expressed through gestures, ignoring, underestimating, scolding, and humiliating children before others. Below are oral abuse expressed through scolding, in teacher's utterance in class teaching learning activity: (1). Context : WHEN TEACHER GETS ANGRY SEEING A NOISY CLASSROOM DUE TO TEACHER'S ABSENCE.

Guru (Teacher) : "Kau tidak dengar guru. Kau pasang belakang guru di depan, kau punya masa depan nanti akan suram."

'kamu tidak mendengarkan guru, membelakangi guru, masa depan mu nanti akan suram'

("You don't listen to the teacher. You faced backward while your teacher standing in front, you're future will be gloomy.")

$$
\begin{aligned}
& \text { Siswa (Student) : } \begin{array}{l}
\text { (terdiam dan tertunduk) } \\
\text { (silenced and head bowed down) }
\end{array} \\
& \text { Guru (Teacher) : "Kau liat saja nanti. Kamu lihat saja nanti." } \\
& \text { (You will see it happen You will see it happen.) } \\
& \text { Siswa } \quad \text { (Terdiam dan tertunduk) } \\
& \text { (silenced and head bowed down). }
\end{aligned}
$$

The above utterances show teacher's expessions of teacher's anger seeing a noisy class due to teacher's absence. Those expressions are swearing words expressed through words of cursing toward students. The objective of that utterance is to make students oppressed and fearful, so will not repeat what he or she has done. The negative effects of that utterance are students feel fearful, under pressure, and afraid, so that appear feelings of uncomfortable and usecure when facing the related teacher. 
Ignoring

Verbal violence/ oral languange abuses happen below expressed by ignoring student. This statement below expressed by a teacher seeing a student asking his friend about a question he has to answer.

(2). Context

: A TEACHER SEES A STUDENTS ASKING HIS FREIND NEXT TO HIM FOR HELPING TO ANSWER QUESTION.

Guru (Teacher) : "Biar saja dia hitung sendiri kan dari tadi dia sudah ikut saya terangkan. Kalau kasi tau-kasi tau sama dia, nanti dia tidak bisa. (sambil guru berlalu meninggalkan siswa yang bersangkutan)"

'biarkan dia berhitung sendiri, karena dia sudah menyimak ketika saya menerangkan tadi. Kalau diberi tahu terus, nanti dia tidak mengerti'

(Let him counts by himself! He has been paying attention to my explanation, hasn't he? If we keep on telling him the answer, he cannot do by himself.")

Siswa : (Terdiam dan tertunduk)

(silenced and head bowed down).

It will be better if the teacher doesn't let the studens remain in their ignorance. In the situation like the above context the teacher should repeat explanation so that the students can understand and able to answer the question well.

\section{UNDERESTIMATING}

Verbal violence/ oral language abuses happen below expressed by ignoring student. This statement below expressed by a teacher seeing a student who cannot do his task. Directly, the teacher says that it should have been not difficult to answer.
(3). Context
: A TEACHER SEEING A STUDENT WHO CANNOT DO HIS TASK.
Guru (Teacher) : "Kita sama-sama duduk di SD dulu ni. Kita pu otak sama-sama main begitu." 'kita sama-sama pernah duduk di SD juga dulu, dan kita tau harus brfikir seperti apa.' (I used to study in Elementary School as well but I knew how to use my brain.")
Siswa (Student) : (terdiam dan tertunduk)
(silenced and head bowed down).

Underestimating student's situation and condition cause students feeling confused and helpless in doing the given questions. It cause students finding difficulty in making decision and actions since he feels unable to do it well and rightly.

\section{SCOLDING}

Teacher's utterances below stated when a teacher finds a student doesn't work his assignment seriously. Teacher's expreesion also followed by action of pinching the student's -namely Elon- stomach. Expression in scolding student is intended to make students feeling fearful/afraid and opressed in order that he will be more serious in working on his assignment, is a form of oral language abuse expressed through scolding.

(4). Context : WHEN A TEACHER IS CHECKING HER STUDENTS JOBS ONE BY ONE.

Guru : "Mana yang kau tulis disitu elon? Bagian mana yang kau tulis di situ?" (setelah mengatakan demikian, guru langsung mencubit perut elon)

Teacher : "Which one you write there Elon? Which part you write there?

(Having said the words, the teacher pinches Elon stomach).

Siswa : (meringis kesakitan)

Student : (suffering pain)

Guru : "Jangan kau ba liat saya pu muka... hitung disitu!"

'Jangan kamu melihat muka saya. Hitung saja disitu!'

("Don't stare at my face....just count!").

Siswa : (tertunduk sambil menulis di bukunya)

Student (head bowd down and writing on his book)

That teacher's expression presents oral language abuse since it makes students feeling threatened by scolding and picthing his stomach.

Humiliating a Student in front of Others.

This following utterances is a quiping which is intended to make the students feeling ashamed/ humiliated in front of others then motifated to study harder for achieving better achievement in class. The teacher gives a kind of quiping by saying that actually if the students using his spare time for studying, he can achieve a good mark, otherwise if he uses his spare time just for playing then his mark will be bad. 
(5). Context : A TEACHER SEES A STUDENTS MAKING MISTAKES IN WORKING HIS ASIGNMENT.

Guru : "Ini juga engko ini, sebenarnya engko pintar matematika. Hanya karena engko ingat main kelereng deng main sepeda, ya begini ini sudah."

'Sebenarnya kamu pintar pada mata pelajaran matematika namun karena kamu mengisi waktu luang dengan bermain kelereng dan sepeda, makanya kamu tidak dapat mengerjakannya."

('Actually you are clever at math but since you have been using your spare time only for playing marble and bicycle, so this is your study result."

Siswa : (Salah tingkah sambil menggaruk kepalanya.)

(Nervously scratching his head)

Factors Causing Verbal Violence Or Verbal Harassment Or Oral Language Abuse Done By Teachers In Kabupaten Sumba Tengah.

Factors causes oral language abuses done by teachers during teaching-learning interaction consist of internal and external factors. Internal factors consists of: past inherited education tradition which is related to teachers' experience suffering verbal language abuse/harassment as victim students; lacking of teachers' understanding on the matter of oral language abuse resulting on uttering words which are quiping and hurting; teachers having problem of lacking vocubularies; teachers' unstable psychological conditions which affect their mental stabilty; and teachers' partial perceptions which give evaluation toward students based on what can be seen. Internal factors which tend to cause verbal violence/oral language abuse are: past inherited education tradition, lacking of teachers' understanding, lacking of teachers' vocubularies, and teachers' partial perceptions on giving evaluation.

External factors are environmental situation and condition which cause teachers having bad habbits of saying verbal harassment such as: local culture habbits of using harsh language and swearing words in daily conversations; teachers' administration tasks which are energy demanding and time consuming can be a stimulant factor for teachers doing verbal abuse; and as a reason of applying discipline when a class is out of control. Among those external factors the ones which tend to cause oral language abuse are local culture habbit and reason for applying discipline. Rionaldi (2014:11) argues that oral language abuses happen because of: lacking of knowledge on the matter of verbal violence itself, teachers' partial perceptions on giving evaluation, existence of psychological problems which hinders emotions maagement, work pressures, autorium pattern which emphasizes on student' obedince under teacher's authority causing teaching larning style is a one way communication, curriculum materials emphasizes cognitive competency and ignoring affective competency..

\section{Conclusions}

The results of the research show that; oral language abuse tends to be done by teachers in the form of linguistic unit as exclamative sentences. Form of verbal language abuse tends to be expressed in the forms of accusing and humiliating a student in front of others. Factors causing verbal violence or verbal harassment or oral language abuse done by teachers in kabupaten sumba tengah are: past inherited education tradition, lacking of knowledge on the matter of verbal violence itself, teachers having problem of lacking vocubularies, administration task demands, reason for applying discipline and local culture habbit.

To avoid oral language abuse, teaching-learning activity has to be planned in such a way to provide a condusive situation. That is why it is needed to do equiping for teachers on the aspects of: teaching model, method, technique, approach, and teaching-learning strategy. Based on that facts, teachers have to gain a sufficent knowledge on oral anguage abuse matter and build a good habbit of using polite language at school. Therefore, teachers have to build a strong habbit of reading books so that the teachers will have a broad knowledge in order to gain enough vocubularies for interaction and communicton especially in school environment.

\section{Bibliography}

Brennan, J. F. 2006. Sejarah dan Sistem Psikologi. Jakarta: PT. Raja Grafindo Persada.

Dardjowidjojo.2014. Psikolinguistik. Pengantar Pemahaman Bahasa Manusia. Jakarta: Yayasana Pustaka Obor Indonesia. 
Fitriana Y, Pratiwi K, dan Susanto, A. V. 2015. Faktor-Faktor yang berhubungan dengan Perilaku Orang Tua dalam Melakukan Kekerasan Verbal Terhadap Anak Usia Pra-Sekolah. Jurnal Psikologi Undip. 14. No $1: 81-93$

Rionaldi, Artur. 2014. Tinjauan Yuridis Terhadap Kekerasan Yang Dilakukan Oknum Guru Terhadap Murid Di Sekolah.Jurnal fakultas hukum Universitas Admajaya Yogyakarta.

Surya, M. 2014. Psikologi Guru.Konsep dan Aplikasi. Bandung: Alfabeta

Sudaryanto. 1993. Metode dan Aneka Teknik Analisis Bahasa: Pengantar Penelitian Wahana Kebudayaan secara Linguistis. Yogyakarta: Duta Wacana University Press.

Sharpe, W. B. Glynn. 2011. Behind the Closed Door: Exploring Teacher Bullying and Abuse of Students, Characteristics of the Teache and Impact. A thesis of Doctor of Education.University of Toronto

Tower, Cynthia, C. 2002.Child Abuse and Neglect. USA: McGraw Hill. 